\title{
Performance Optimization Viewing Wawotobi Irrigation Network
}

\author{
Ahmad Syarif Sukri*1, Andi Bahrun' ${ }^{2}$, Samdin $^{3}$, Tupaila Hemon ${ }^{2}$ \& Hasbullah Syaf ${ }^{2}$ \\ ${ }^{* 1}$ Faculty of Engineering, Halu Oleo University-Kendari, 93723-Indonesia, \\ ${ }^{2}$ Faculty of Agriculture, Halu Oleo University-Kendari, 93723 Indonesia. \\ ${ }^{3}$ Faculty of Economics, University of Halu Oleo-Kendari,93723 Indonesia.
}

ORCID: 0000-0002-0482-7908 (Ahmed Syarif Sukri)

\begin{abstract}
Many countries continue to struggle hard to face water scarcity, water scarcity, and availability in Indonesia very much depending on climate conditions, local and global weather. The irrigation system development and management program in Indonesia in the field of food sovereignty is a leading sector enshrined in NAWA CITA through economic independence. The problem of optimizing water use more effectively and efficiently is often an indication of the low performance of water distribution efficiency and the lack of maintenance operating costs. Wawotobi irrigation has great water potential but there are still areas that do not get water according to their needs.

The results of research on optimizing the Wawotobi irrigation network system on the performance of the hydrological conditions and hydraulic conditions are quite optimal, the Optimization index between the existing conditions and the performance value of CSI $=0.52$ is quite optimal. Based on SEM analysis that the estimated value for performance is positive, for volume analysis (VE) in good condition. As for the coefficient of efficiency $(\mathrm{CE})=0.84$ optimization is very efficient, with Hydraulic performance of Wawotobi irrigation system $62.46 \%$ less optimal performance index. The optimization model of the Wawotobi irrigation network system to the performance and the existing condition of the KR model is $0.129 . \mathrm{KJ}+\mathrm{e}$, the better the existing conditions, the better the service performance.
\end{abstract}

\section{Keywords: Optimization, Performance, model, Irrigation}

\section{INTRODUCTION}

Water availability is highly dependent on natural factors such as climate conditions, local and global weather. Climatic and weather conditions are very influential on the distribution of rainfall in each region, Indonesia has a tropical climate experiencing two seasons namely the rainy season and the dry season in one year[1]. The availability of water at this time has begun to decrease due to global warming which could have an impact on the condition of the availability of water sources and the distribution of water for agricultural purposes which decreases in quantity and volume. Improvement of irrigation reliability, quality and quantity of available water has serious impacts and cause problems in the optimal water management, use and utilization systems such as surface water and groundwater are very important in the management and preparation of water. Increased food production is influenced by the availability of water sources and management systems that are efficient and optimal in agriculture[11,15,18].

The Wawotobi irrigation network system is indicative of the low performance of the existing irrigation network system. To overcome the problem, it is necessary to conduct an analysis based on the selection of alternative management of appropriate and consistent irrigation operations including conditions: 1) water availability, 2) water sources, 3) water requirements, 4) buildings, 5) water discharge, 6) water distribution, 7) irrigation conditions, 8) rice fields, 9) cropping patterns, 10) availability of tools, 11) farmers, 12) officers, 13) P3A groups, and 14) operation and maintenance. The current condition of the Wawotobi irrigation area is that there are still areas that are not yet optimal in getting water distribution, while the potential of water sources in the Wawotobi dam is so great. Based on the Wawotobi irrigation conditions, researchers are very interested in studying the optimization of the performance of the Wawotobi irrigation network system as seen from the analysis of the effect of optimizing the performance on existing conditions, optimizing the existing condition performance model, and analyzing the hydraulic and hydrological conditions in the Wawotobi network system[2,3,10,14].

Based on the previous description, the purpose of this study is to determine the optimization model of the Wawotobi irrigation network system against the existing performance and conditions, based on survey data and interviews using the AMOS18 program.

\section{LITERATURE REVIEW}

\subsection{Location Overview}

This research was carried out in the irrigation area of Wawotobi, Konawe Regency, Southeast Sulawesi Province, Indonesia, located in the geographical position of $02^{0} 45^{\prime}-04^{0} 15^{\prime} \mathrm{LS}$, and $121^{0} 15^{\prime}-123^{0} 30^{\prime}$ BT East with the right and left intake taken with seven doors, and weir width $99.00 \mathrm{~m}$ and river width 82.00 $\mathrm{m}$, potential irrigation area $\pm 20,458$ ha, functional area 9,442 ha, with twice planting a year. The length of the channel is $153,156 \mathrm{~km}$, the number of buildings for tapping 127 units with 221 complementary buildings, the length of the disposal channel $130 \mathrm{~km}$, with a level of rice production of $4.4-7.2$ ton.ha-1[2].

\subsection{Data Collection}

The research population of the Wawotobi irrigation area, while the study sample used simple random sampling, namely 
International Journal of Engineering Research and Technology. ISSN 0974-3154, Volume 13, Number 6 (2020), pp. 1101-1109

(C) International Research Publication House. https://dx.doi.org/10.37624/IJERT/13.6.2020.1101-1109

irrigation networks, area, flow, and farmers, with a total area of 12,293.16 ha of irrigated rice fields, an observation sample of 388 points was obtained.

Averaged one dependence estimators (AODE) can provide good accuracy when performing binary classification. Also their training and testing times are relatively fast compared to other popular algorithms [7].

Table 1. Proportional Stratified Random Sampling Distribution Points of the Wawotobi Irrigation Area

\begin{tabular}{|c|c|c|c|}
\hline No & Irrigation service area & Population & Point \\
\hline 1 & Lambuya & $(825 / 12.293,16) \quad * 388$ & 26 \\
\hline 2 & Uepai & $(639 / 12.293,16)$ & 20 \\
\hline 3 & Konawe & $(327 / 12.293,16)$ & 11 \\
\hline 4 & Unaaha & $(766 / 12.293,16)$ & 24 \\
\hline 5 & Wonggeduku & $(2.702 / 12.293,16) * 388$ & 85 \\
\hline 6 & Wonggeduku Barat & $(2.353 / 12.293,16) \quad * 388$ & 74 \\
\hline 7 & Wawotobi & $(1.963 / 12.293,16) \quad * 388$ & 62 \\
\hline 8 & Pondidaha & $(1.735 / 12.293,16) \quad * 388$ & 55 \\
\hline 9 & Tongauna & $(983,16 / 12.293,16) * 388$ & 31 \\
\hline \multicolumn{3}{|c|}{ total } & 388 \\
\hline
\end{tabular}

\subsection{Research Implementation}

Analysis of the optimization of existing irrigation networks is an evaluation of the performance of irrigation network services in existing conditions. The operational aspects of irrigation networks are based on indicators, and a general assessment of the availability, sources, needs, buildings, debit, water distribution, irrigation, rice fields, cropping patterns, tools, farmers, officers, P3A, O and P [7,13, 17,20,23].

\subsection{Hydraulic Conditions of Wawotobi Irrigation Network System Performance}

Hydraulic condition analysis of irrigation network performance using flow velocity (V) data on channels, depth of flow (h), channel dimensions, and flow (Q), as well as the condition of buildings, channels, and supporting facilities, these data are obtained from direct observation sources in the field [7,13,23]. Methods in the analysis of buildings, primary channels, and secondary channels, in the following order:

a) Determine the performance of physical facilities in the main building, the carrier channel, the building in the carrier channel, and the disposal and building channels.

b) Determine the performance of road, office, housing, and planting productivity facilities.

c) Determine the performance of supporting facilities, organization, documentation, and P3A.

d) Recapitulation of performance results, if the index value of $80-100 \%$ is very good, the index value of $70-79 \%$ is good, the index value is $55-69 \%$ less, if the index value $<55 \%$ is bad $[2,10,14,17]$.

\subsection{Farmer Satisfaction of Optimization Performance of Wawotobi Irrigation Network System.}

Farmer's satisfaction on the performance of irrigation network services using the Importance Performance Analysis (IPA) and Customer Satisfaction Index (CSI) methods, the analysis method is carried out by combining factors of importance and satisfaction levels of irrigation users in the graph, making it easier to explain the data. The interpretation of natural science charts in four quadrants is based on the measurement results obtained from the results of the questionnaire in the field $[4,8,9,12,16,22]$.

Analysis of the effect of satisfaction on the performance of the irrigation network system uses Structural Equation Modeling (SEM) to determine the variables that have a dominant influence. Structural testing using the AMOS version 18.0 program will convert these model specifications into structural equations and measurement model specification equations [5,6]. Structural equations are formulated to express the quality relationship between variables, as shown in the following equation:

information:

$$
\mathrm{Y}=\beta \mathrm{X}+\mathrm{e}
$$

$\mathrm{Y}=$ satisfaction of irrigation network users

$\mathrm{X}=$ Irrigation network system performance

$\mathrm{e}=$ Error measuring latent variable performance

$\beta=$ Regression Weight (regression coefficient Unstdanardized Beta)

Analysis of the optimization of the irrigation network system is carried out using the Importance Performance Analysis (IPA) method to find out the performance of the irrigation network system, which is by following under the expectations of the users of irrigation services that should exist $[9,12,19,21]$. Irrigation network performance is carried out by multiplying the importance and satisfaction weight of each respondent so that the average performance index of each research parameter is obtained, as shown in Eq.

$$
\mathrm{Tki}=\frac{X i}{Y i} \times 100 \%
$$

information:

Tki: Compliance level of the respondent

$\mathrm{Xi}$ : Scoring score on irrigation network performance

Yi: Score of interests or expectations of irrigation users 
The horizontal axis (X) scores the level of implementation, while the upright axis (Y) scores the level of expectations (expectations), in the simplification of the formula, then every factor that affects the satisfaction of irrigation users is shown in the equation:

$$
\begin{gathered}
\bar{X}=\frac{\sum X i}{n} \\
\bar{Y}=\frac{\sum Y i}{n}
\end{gathered}
$$

A Cartesian diagram is a structure divided into four parts that are bounded by two lines that intersect perpendicular to the points $(\mathrm{X}, \mathrm{Y})$, the symbol $\mathrm{X}$ is the average of the average score of satisfaction level, and $\mathrm{Y}$ is the average of the average importance score calculated using the equation $[9,12,19,21]$ :

$$
\begin{aligned}
& \mathrm{Q}=\frac{\sum_{i=1}^{n} \overline{X \imath}}{k} \\
& \mathrm{P}=\frac{\sum_{i=1}^{n} \overline{Y l}}{k}
\end{aligned}
$$

Information :

$\mathrm{K}=$ The number of facts that can affect user satisfaction $\mathrm{Q}=$ Midpoint of the performance level score

$\mathrm{P}=$ Midpoint of expectation level score

Irrigation user satisfaction analysis is done using the customer satisfaction index (customer satisfaction index (CSI)) is a measurement to determine the overall level of satisfaction with an approach that considers the expected level of the factors measured, to get the satisfaction index number the following steps are taken: [22]

1) Determine the Mean Importance Score (MIS)

MIS value of the average level of consumer expectations of each variable or attribute shown in the equation;

$$
\operatorname{MIS}_{t}=\frac{\left(\sum_{t=1}^{n} Y_{t}\right)}{n}
$$

information:

$\mathrm{n}=$ Number of respondents

$\mathrm{Yi}=\mathrm{i}$-th expectation value

2) Determine the Mean Satisfaction Score (MSS)

MSS value of the average level of reality felt by each variable:

$$
\operatorname{MSS}_{t}=\frac{\left(\sum_{t=1}^{n} X_{t}\right)}{n}
$$

information:

$\mathrm{Xi}=\mathrm{i}$ Reality of Xth Attribute Value

\section{3) Make a Weight Factor (WF)}

This weight represents the MIS value per attribute to the total MIS of all attributes.

$$
W_{t}=\frac{M I S_{t}}{\sum_{t=1}^{p} M I S_{t}}
$$

\section{4) Make a Weight Score (WS)}

This weight is a multiplication of WF with the average level of reality of service perceived by irrigation network users as MSS (Mean Satisfaction Score);

$W S_{t}=W F_{t} x M S S_{i}$

\section{5) Determine CSI}

The equation used to determine CSI:

$$
C S I=\frac{\sum_{t=1}^{p} W S_{t}}{H S} \times 100 \%
$$

Information :

$\mathrm{p}=$ attribute of $\mathrm{p}$ interests

HS $=($ Highest Scale) The maximum scale used

2. ML algorithms were used to build Model, as in the diagram. Three important performance metrices [20] were used for the comparison; namely accuracy, true positive rate and false alarm rate.

Table 2. Criteria for Customer Satisfaction Index Value [12]

\begin{tabular}{|c|c|}
\hline Score CSI & CSI Criteria \\
\hline $0.81-1.00$ & Very satisfied \\
\hline $0.66-0.80$ & Satisfied \\
\hline $0.51-0.65$ & Quite satisfied \\
\hline $0.35-0.50$ & Less satisfied \\
\hline $0.00-0.34$ & Not satisfied \\
\hline
\end{tabular}

\subsection{Performance of the Hydrological Condition of the Wawotobi Irrigation Network System}

Analysis of the effect of hydrology on the performance of irrigation network systems uses secondary data, namely hydrology, meteorologies such as rainfall, evapotranspiration, and water needs, and watersheds (DAS) obtained from the Sulawesi River Basin IV[2]. Data analysis techniques were carried out in the following order $[7,13,17,23,20]$ :

1) Input rainfall data, sort data according to year, month and daily.

2) Input rainfall data as monthly as by following per under the year.

3) Input the measured debit data as soon as a month.

4) Input mock parameter values according to watershed conditions.

5) Determine the potential Evapotranspiration value (Eto) using the Fj. Mock analysis.

6) Determine the actual Evapotranspiration value (Ea).

7) Determine the water balance value.

8) Determine runoff and water storage

9) Determine the amount of discharge (Qs)

10) Evaluate the similarity of calculated debit value (Qcal) with measured debit (Qobs)

11) Analysis of Q50, Q80, Q90, and Q95 mainstays.

12) Measured discharge analysis (Qobs)

13) Calculated debit analysis (Qcal)

14) Analysis of the degree of saturation (R), flow alignment (VC),

15) Determine the value of efficiency (CE), if CE $>0.75$ optimization is very efficient, $0.36<\mathrm{CE}<0.75$ optimization is quite efficient, and if $\mathrm{CE}<0.36$ optimization is inefficient. 


\section{RESULTS AND DISCUSSION}

The actual evapotranspiration that occurred in Wawotobi irrigation for the smallest occurred in June II amounted to 34.63 mm.month-1 and the largest occurred in December I amounted to $78.33 \mathrm{~mm}$.month-1. The value of water surplus obtained is between 0 - $105 \mathrm{~mm}$. Month-1 the largest occurred in February II of $137.05 \mathrm{~mm}$. month-1. The infiltration coefficient is determined by the porosity and slope conditions of the drainage area. Infiltration continues to occur in the Wawotobi irrigation area obtained from 0 to $34.26 \mathrm{~mm}$. Month-1 with groundwater storage values obtained between 0.34 - $37.89 \mathrm{~mm}$. Month-1. year, the largest river discharge occurred in February II = $356.23 \mathrm{~m} 3 / \mathrm{s}$ with a watershed area $=3415.24 \mathrm{Km} 2$. While the largest debit occurred in June $\mathrm{I}=288.24 \mathrm{~m} 3 / \mathrm{s}$.

\subsection{Mainstay Debit Analysis}

The mainstay discharge values analyzed in this study are Q50, Q80, Q90 and Q95 with the largest value, for Q50 = $255.43 \mathrm{~m} 3 / \mathrm{s}, \mathrm{Q} 80=97.82 \mathrm{~m} 3 / \mathrm{s}, \mathrm{Q} 90=92.54 \mathrm{~m} 3 / \mathrm{s}$ Q95 $=80,65 \mathrm{~m} 3 / \mathrm{s}$. for the analysis of recapitulation of measured debit / observation using measured debit multiplied by 0.864 and multiplied by the number of days in the middle of the month. In 2014 the annual discharge summary was Q2014 = 50,883.46 m3 / s., Q2015 = 42,484.96 m3 / s., Q2016 = 36,694.34 m3 / s, and Q2017 = $24,125.96 \mathrm{~m} 3 / \mathrm{s}$.

\subsection{Debit Optimization Analysis}

The results of the analysis obtained the value of $\mathrm{R}$ in 2014 $=0.73,2015=0.75,2016=0.79$ and $2017=0.60$. For the value of VE shows a number of not more than $5 \%$, the condition of the flow discharge is good, with a flow of $\mathrm{CE}$ values obtained 0.84 , very efficient conditions, the simulation conditions can be seen in Figure 1.

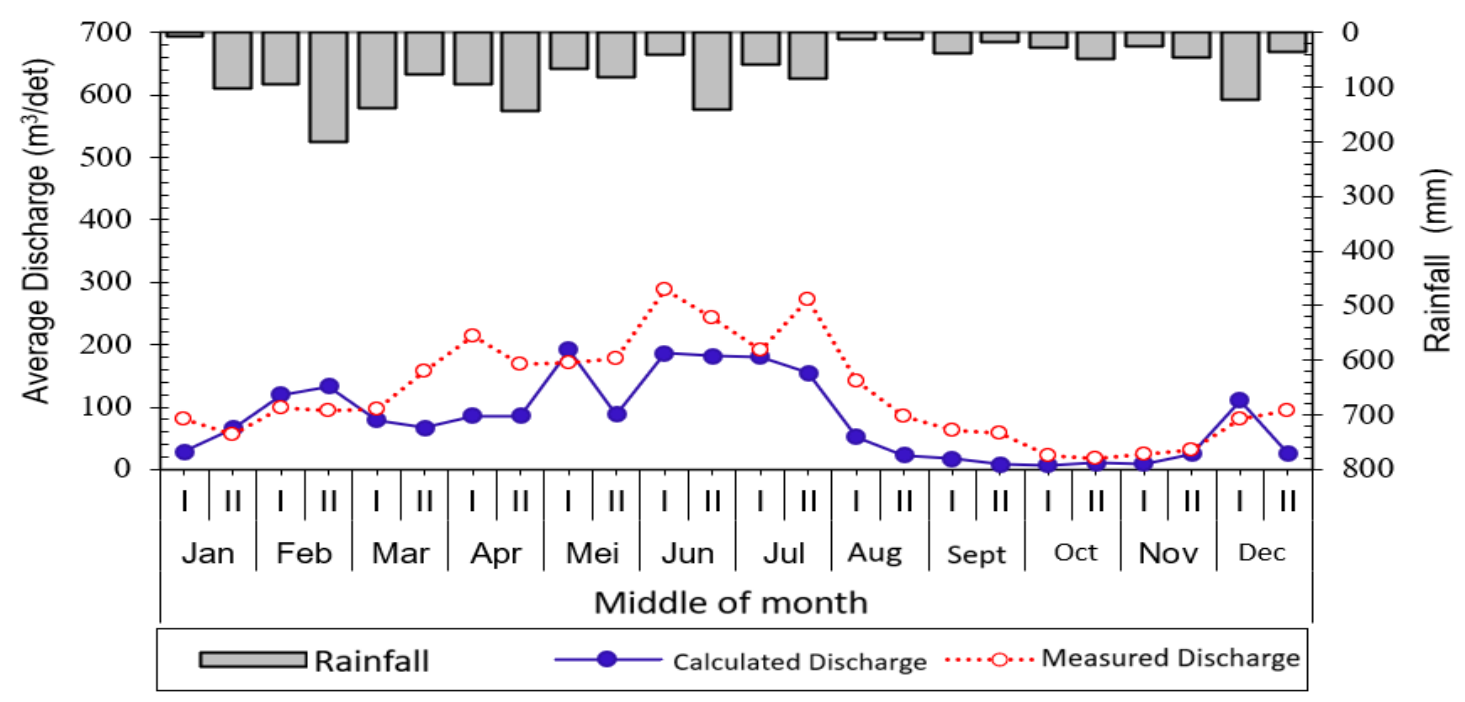

Fig 1. Graph Relationship of Rainfall, Calculated Debit and Measured Debit in 2014 - 2017.

Figure 1, provides an overview of the conditions in 2014 to 2017 with maximum rainfall occurring in February II, while for the condition of the measured discharge flow in the Wawotobi dam area the largest was in June I and for the analysis of the calculated discharge obtained the largest discharge was in May I, the condition of water availability from 2014-2017 there is a relative rainfall every month, this condition shows that there is a very close relationship between rainfall and discharge that occurs in a watershed
Wawotobi irrigation area water requirements obtained the maximum NFR value occurred in February with a value of $0.85 \mathrm{l} / \mathrm{s} / \mathrm{ha}$ with a value of $\mathrm{DR}=1.31 \mathrm{l} / \mathrm{s} / \mathrm{ha}$. Wawotobi irrigation network efficiency, for tertiary canals 0.80 with water demand levels of $1.16 \mathrm{l} / \mathrm{s} / \mathrm{ha}$, secondary channel efficiency 0.72 with water demand levels of $1.291 / \mathrm{s} / \mathrm{ha}$ and for primary channel efficiency of 0.65 with a water level of $1.43 \mathrm{l} / \mathrm{s} / \mathrm{ha}$.

Table 3. Monthly Average NFR Value of DI. Wawotobi

\begin{tabular}{|c|c|c|c|c|c|c|c|c|c|c|c|c|}
\hline \multirow{2}{*}{ Information } & \multicolumn{12}{|c|}{ Month } \\
\hline & Jan & Feb & Mar & Apr & May & Jun & Jul & Aug & Sep & Oct & Nov & Dec \\
\hline $\mathrm{NFR}(\mathrm{lt} / \mathrm{s} / \mathrm{ha})$ & 0,65 & 0,85 & 0,64 & 0,41 & 0,58 & 0,79 & 0,60 & 0,60 & 0,59 & 0,50 & 0,53 & 0,33 \\
\hline DR (lt/s/ha) & 0,99 & 1,31 & 0,98 & 0,63 & 0,89 & 1,22 & 0,92 & 0,92 & 0,91 & 0,76 & 0,81 & 0,50 \\
\hline
\end{tabular}




\subsection{Analysis of Existing Performance of Wawotobi Irrigation Network}

Table 4 shows the condition of planting productivity indicators obtained $12.61 \%$, which consists of sub-indicators of meeting water needs, the realization of planting area and rice productivity. Supporting facilities indicators obtained $4.425 \%$ with sub-indicators are equipment, transportation, office equipment, and communication tools. Personnel organization indicators obtained performance value $7.50 \%$ consisting of sub-indicators of the organization and personnel.

Table 4. Results of Wawotobi Irrigation Network Performance Analysis

\begin{tabular}{|c|c|c|c|c|c|}
\hline No & Description & $\begin{array}{c}\text { Section } \\
\text { Weight (\%) }\end{array}$ & $\begin{array}{c}\text { Maximum } \\
\text { Index (\%) }\end{array}$ & $\begin{array}{c}\text { Condition } \\
\text { Index } \\
\text { component }\end{array}$ & Performance \\
\hline I & Physical infrastructure & 32.90 & 45.00 & 73.11 & Well \\
\hline II & Planting Productivity & 12.61 & 15.00 & 84,07 & Very good \\
\hline III & Supporting Targets & 4.43 & 10.00 & 44.25 & Ugly \\
\hline IV & Personnel Organization & 7.50 & 15.00 & 50.00 & Ugly \\
\hline V & Documentation & 2.85 & 5,00 & 57.00 & Less \\
\hline VI & $\begin{array}{c}\text { Water User Farmers' } \\
\text { Association }\end{array}$ & 2.18 & 10.00 & 21.75 & Ugly \\
\hline \multicolumn{2}{|r|}{ DI Conditions Index. Wawotobi } & & 100,00 & & Less \\
\hline
\end{tabular}

Documentation indicator with a value of $2.85 \%$ with subsection indicators of irrigation area data book, maps, and pictures, and Indicator P3A/GP3A/IP3A obtained $2.18 \%$ results, and the results of the performance of the Wawotobi irrigation network system value obtained $62,46 \%$ with poor performance index. This suggests that the current Wawotobi irrigation network system is less than optimal in achieving the performance of the irrigation network system, both in terms of physical infrastructure indicators, planting productivity, supporting facilities, personnel organizations, documentation, and $\mathrm{P} 3 \mathrm{~A}$ indicators.

\subsection{Optimization of Wawotobi Irrigation Network Services Existing Conditions}

Wawotobi irrigation network with an irrigation network length of $153,156.00 \mathrm{~km}$ consisting of left primary channel 1,639.19 $\mathrm{km}(1.07 \%)$, right primary channel 3,218.10 km (2.10\%), left secondary channel $124,895.69 \mathrm{~km}(81.55 \%)$, right secondary channel $23.403 .02 \mathrm{~km}(15.28 \%)$.

Based on Table 6, shows the performance of irrigation networks and the value of farmers' interests in the Wawotobi irrigation network. The gap between optimization and existing conditions on the performance indicators of the Wawotobi irrigation system service, indicators that have large gaps are indicators of needs (86.58), irrigation (86.78), and cropping patterns (90.29), with an average value 93.01. Irrigation network farmer farmers consider that in general the existence of an irrigation network system is quite optimal.

The optimal level of performance of the Wawotobi irrigation network system will be described in a Cartesian diagram.

Table 5. Position Indicators in the Existing Wawotobi Irrigation Network

\begin{tabular}{|c|l|c|c|c|c|c|c|}
\hline \multirow{2}{*}{ No } & \multicolumn{1}{|c|}{ Indicator } & Performace (x) & Real Condition (Y) & Tki & Weight & Score & CSI \\
\cline { 2 - 7 } & \multicolumn{1}{|c|}{$\mathbf{A}$} & $\mathbf{C}$ & $\mathbf{B}$ & $\mathbf{D}$ & $\mathbf{E}$ & $\mathbf{F}$ & $\mathbf{G}$ \\
\hline 1. & Availability & 2,69 & 2,93 & 92,04 & 1,04 & 2,72 & 0,54 \\
\hline 2. & Source & 2,74 & 2,81 & 97,51 & 1,00 & 2,61 & 0,52 \\
\hline 3. & Needs & 2,59 & 2,99 & 86,58 & 1,06 & 2,77 & 0,55 \\
\hline 4. & Building & 2,61 & 2,82 & 92,65 & 1,00 & 2,62 & 0,52 \\
\hline 5. & Debit & 2,65 & 2,70 & 98,40 & 0,96 & 2,51 & 0,50 \\
\hline 6. & Water Distribution & 2,62 & 2,86 & 91,59 & 1,02 & 2,66 & 0,53 \\
\hline 7. & Irrigation & 2,55 & 2,94 & 86,78 & 1,04 & 2,73 & 0,55 \\
\hline 8. & Rice fields & 2,62 & 2,83 & 92,37 & 1,01 & 2,63 & 0,53 \\
\hline 9. & Cropping pattern & 2,60 & 2,88 & 90,29 & 1,03 & 2,68 & 0,54 \\
\hline 10. & Tool & 2,54 & 2,79 & 91,15 & 0,99 & 2,59 & 0,52 \\
\hline 11. & Farmers & 2,60 & 2,86 & 90,76 & 1,02 & 2,66 & 0,53 \\
\hline 12. & Officer & 2,54 & 2,72 & 93,45 & 0,97 & 2,52 & 0,50 \\
\hline 13. & P3A & 2,46 & 2,59 & 94,83 & 0,92 & 2,40 & 0,48 \\
\hline 14. & O and P & 2,76 & 2,66 & 103,68 & 0,95 & 2,47 & 0,49 \\
\hline \multicolumn{2}{|c|}{ total } & $\mathbf{3 6 , 5 7}$ & $\mathbf{3 9 , 3 7}$ & $\mathbf{1 3 0 2 , 0 7}$ & $\mathbf{1 4 , 0 0}$ & $\mathbf{3 6 , 5 7}$ & $\mathbf{7 , 3 1}$ \\
\hline \multicolumn{2}{|c|}{ average } & $\mathbf{2 , 6 1}$ & $\mathbf{2 , 8 1}$ & $\mathbf{9 3 , 0 1}$ & Hasil CS Indeks & $\mathbf{0 , 5 2}$ \\
\hline
\end{tabular}




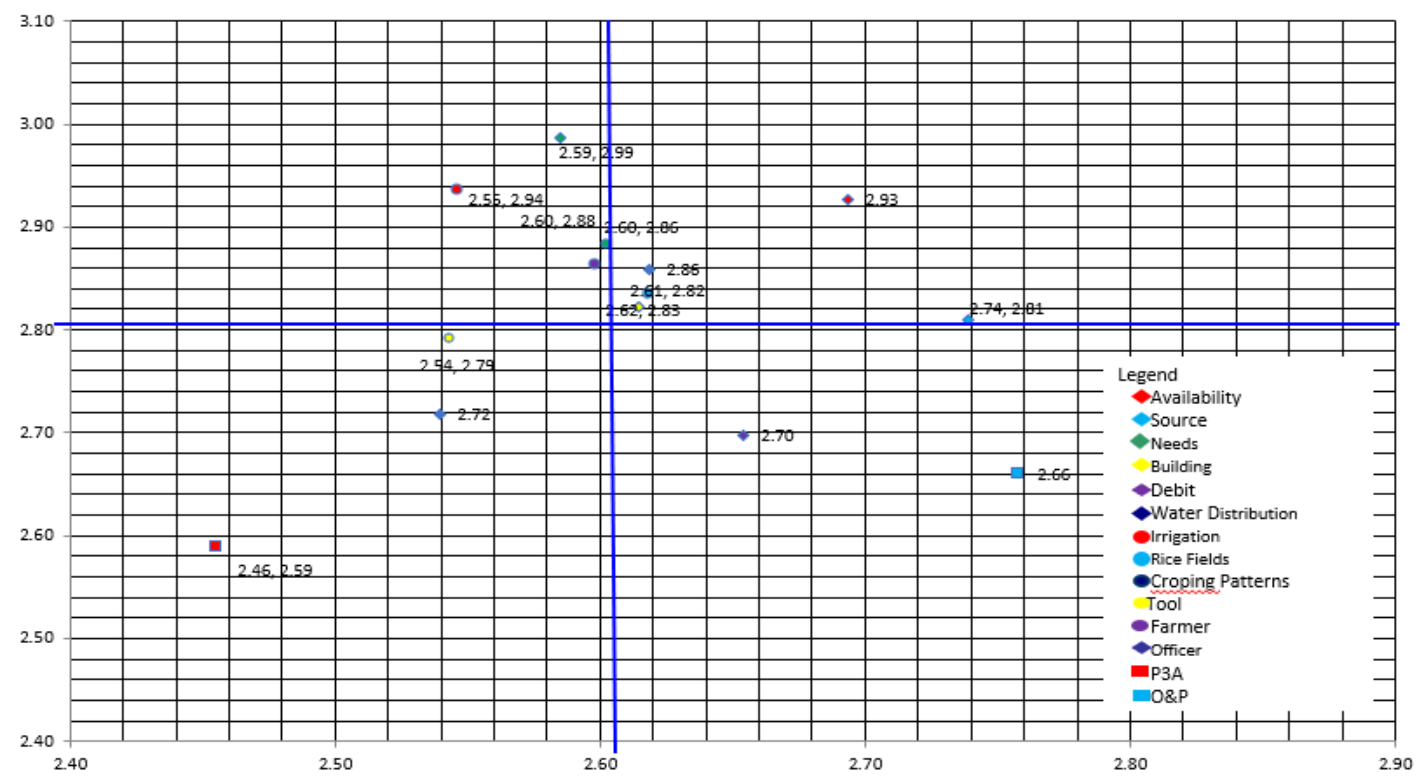

Fig. 2. IPA Cartesian Diagram Optimization of Wawotobi Irrigation Network System Existing Condition

Based on Figure 2. the Cartesian diagram shows that in quadrant I as the main priority there are indicators of irrigation, farmers, cropping patterns, and needs, in quadrant II that is expected to be able to maintain achievement there are indicators of availability, buildings, rice fields, sources, and water distribution. Whereas in quadrant III as excessive quadrant there are indicators of discharge and $\mathrm{O}$ and $\mathrm{P}$, while for quadrant IV there are indicators of equipment, officers, and P3A. The evaluation index of Wawotobi irrigation system performance optimization between existing conditions and performance, overall CSI value of 0.52 where the condition of the irrigation network system is quite optimal

\subsection{Optimization Model of Wawotobi Irrigation Network System on Existing Performance and Conditions}

Calculation of measurement models through confirmatory factor analysis for each latent variable based on the model built and the measurement indicators in this study can be explained as follows:

\section{a) Estimation of the Loading Factor Forming the Satisfaction Latent Variable}

The results of the estimation of the measurement model of latent variable optimization consists of four manifest variables (observed variables), namely: cropping pattern, officer, P3A, and OP.

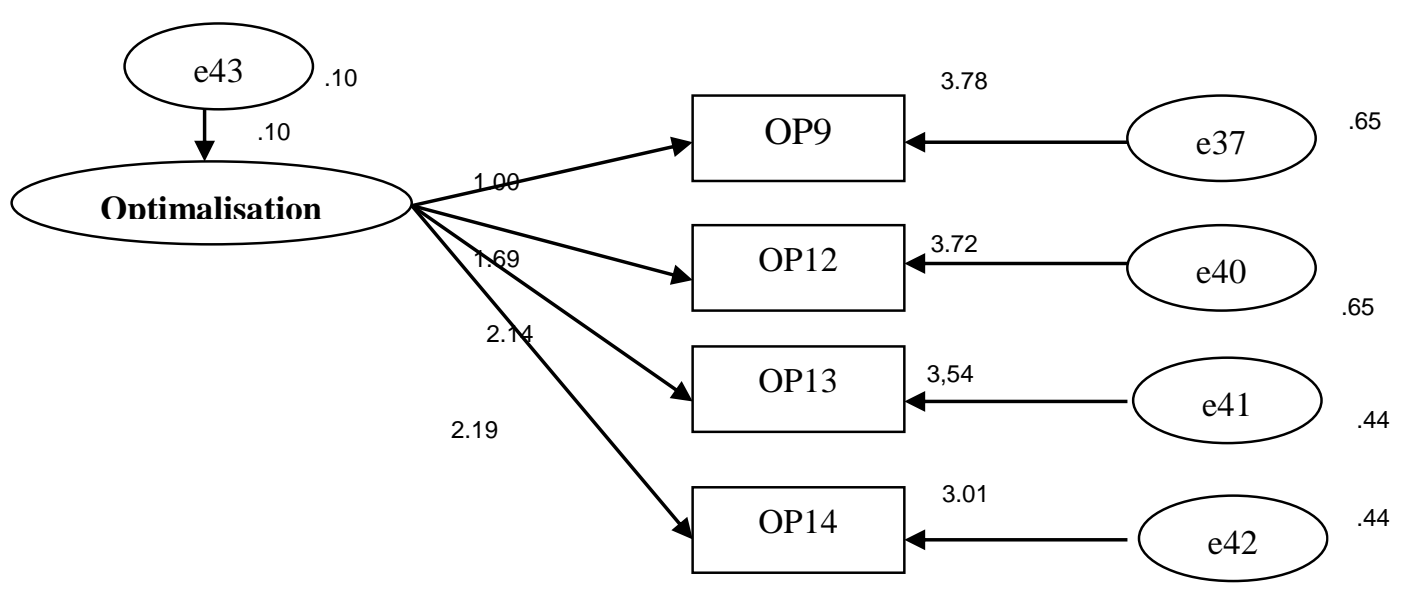

Fig. 3. Confirmatory Factor Measurement Model of Latent Variable Optimization of the Existing Wawotobi Irrigation Network System

Based on Figure 3, the structural model can be entered into the equation as follows:

$\mathrm{OP}=\lambda . \mathrm{OP}+\mathrm{e}$

$\mathrm{OP} 9=1.0 \mathrm{KP} 9+\mathrm{e} 37$

$\mathrm{OP} 12=1.695 \mathrm{KP} 12+\mathrm{e} 40$ 
International Journal of Engineering Research and Technology. ISSN 0974-3154, Volume 13, Number 6 (2020), pp. 1101-1109

(C) International Research Publication House. https://dx.doi.org/10.37624/IJERT/13.6.2020.1101-1109

$\mathrm{OP} 13=2,140 \mathrm{KP} 13+\mathrm{e} 41$

$\mathrm{OP} 14=2.192 \mathrm{KP} 14+\mathrm{e} 42$

Table 6. Measurement Model of Wawotobi Irrigation Network Optimization of Existing Conditions

\begin{tabular}{|c|c|c|c|c|c|}
\hline information & derection & description & Estimation & C.R. & P \\
\hline OP9 & $\longleftarrow$ & Optimiation & 1,00 & 0 &, 000 \\
\hline OP12 & $\longleftarrow$ & Optimiation & 1,695 & 4,062 &, 000 \\
\hline OP13 & $\longleftarrow$ & Optimiation & 2,140 & 4,344 &, 000 \\
\hline OP14 & $\longleftarrow$ & Optimiation & 2,192 & 4,348 &, 000 \\
\hline
\end{tabular}

b) Estimating Loading Forming Factors Forming Performance Latent Variables

The estimation results of the measurement model of latent performance variables consist of two manifest variables (observed variables), namely: officers and P3A. The measurement model for confirmatory factor analysis for each of the observed performance variables can be seen from the factor loading and probability values that reflect the level of significance and the amount of contribution in the formation of latent variables of performance through standardized regression weights.

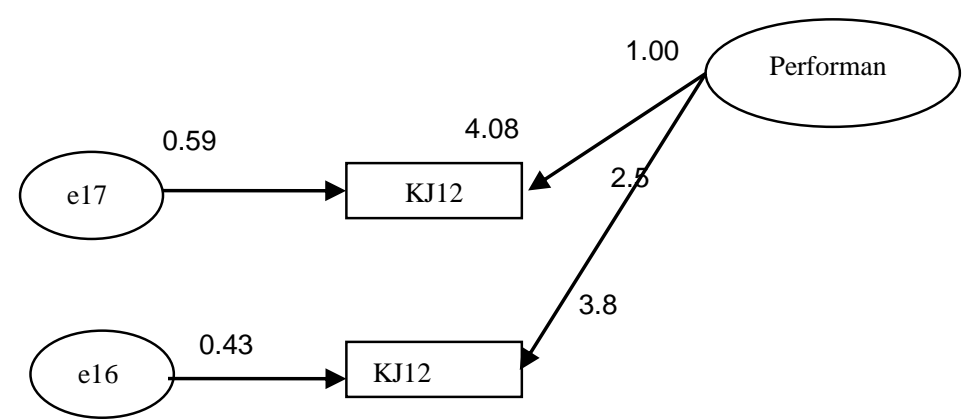

Fi 4. Confirmatory Factor Measurement Model of Latent Performance Variables Wawotobi Irrigation Network Existing Condition

Based on Figure 4, the structural model can then be entered into the equation as follows:

This section should be typed in character size 10pt Times New Roman, Justified

$\mathrm{KJ}=\lambda \mathrm{KJ}+\mathrm{e}$

$\mathrm{KJ} 12=1,00 \mathrm{KJ} 12+\mathrm{e} 17$

$\mathrm{KJ} 13=2,589 \mathrm{KJ} 13+\mathrm{e} 16$
The estimation results of the measurement model of latent performance variables using confirmatory factor analysis are shown in Figure 4, the formation consists of one manifest variable having a factor loading value $(\lambda)$ and the probability of all indicator variables below the cut-off point of 0.40 or $40 \%$ and probability values below $\alpha=0.05$.

Table 7. Wawotobi Irrigation Network Performance Variable Measurement Model Existing Conditions

\begin{tabular}{|c|l|c|c|c|c|}
\hline information & derection & description & Estimation & C.R. & P \\
\hline KJ13 & $\longleftarrow$ & performance & 2,589 & 1,175 & 0,240 \\
\hline KJ12 & $\longleftarrow$ & performance & 1,000 & 1,020 & 0,130 \\
\hline
\end{tabular}

\section{c) Estimating Loading Forming Factors of Latent Variables of Interest}

The results of the estimation model of the measurement of the latent variables of the existing conditions consist of four manifest variables (observed variables): buildings, water distribution, rice fields, and cropping patterns. Based on Figure 5, the structural model can then be entered into the latent equation of interest by using confirmatory factor analysis as shown in Figure as follows:

$\mathrm{KR}=\lambda \mathrm{KR}+\mathrm{e}$

$\mathrm{KR} 4=1,00 \mathrm{KR} 4+\mathrm{e} 11$

$$
\begin{aligned}
& \mathrm{KR} 6=1,18 \mathrm{~K} 6+\mathrm{e} 9 \\
& \mathrm{KR} 8=1,232 \mathrm{KR} 8+\mathrm{e} 7 \\
& \mathrm{KR} 9=0,935 \mathrm{KR} 9+\mathrm{e} 6
\end{aligned}
$$

The estimation results of the measurement model variable 5 , the formation consists of four manifest variables having a factor loading value $(\lambda)$ and the probability of all indicator variables below the cut-off point of 0.40 or $40 \%$ and a probability value below $\alpha=0.05$. 


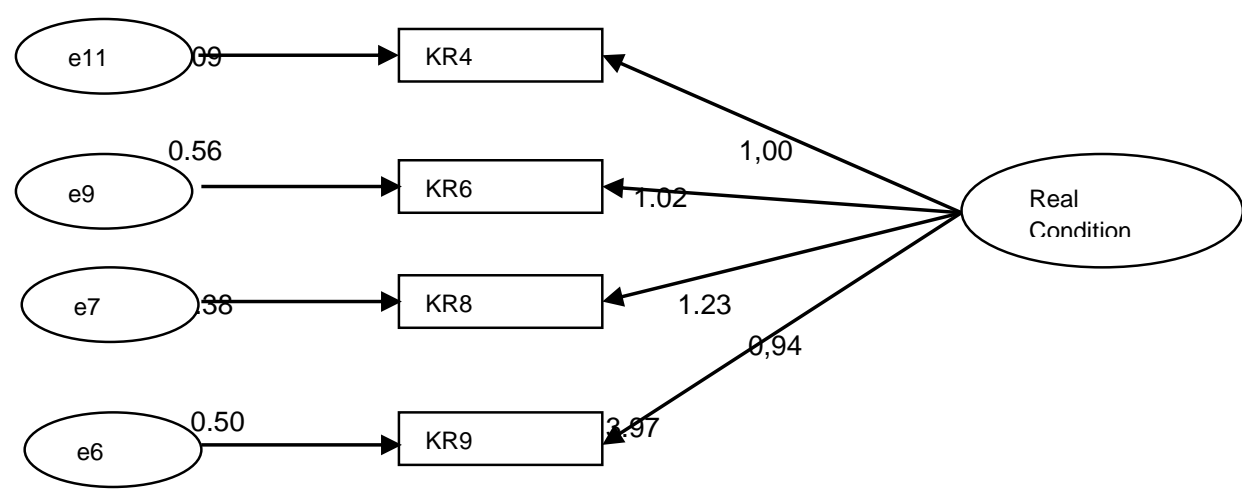

Fig 5. Confirmatory Factor Measurement Model of Latent Interest Variables Wawotobi Irrigation Network Existing Condition

The measurement model for latent variables of interest is shown in Table 8.

Table 8. Model of Interest Variable Measurement of Existing Condition of Wawotobi Irrigation Network System

\begin{tabular}{|c|l|c|c|c|c|}
\hline information & derection & description & Estimation & C.R. & P \\
\hline KR4 & & Real Condition & 1,00 & 2,321 &, 006 \\
\hline KR6 & $\longleftarrow$ & Real Condition & 1,018 & 2,675 &, 007 \\
\hline KR8 & $\longleftarrow$ & Real Condition & 1,232 & 2,722 &, 006 \\
\hline KR9 & $\longleftarrow$ & Real Condition & 0,935 & 2,613 &, 009 \\
\hline
\end{tabular}

\section{d) Goodness of Fit Test}

For this SEM test, several suitability indexes and cut-off values are needed to be used in testing a model.

The test of the model hypothesis shows that this model is by following per under the data or fit to the available data as seen from the level of significance of the chi-square model of 44.769 must be smaller than the chi-square calculated chains $(0.05 ; \mathrm{DF})=84.82$. The probability index value of 0.083 is greater than 0.05 and the RMSEA value of 0.005 must be smaller than 0.08 . Because the chi-square value and CMIN / DF are at the value of $1.375 \leq 2.00$, the evaluation of the model is good, this model can be accepted using authentic data from the field and the resulting model can be used to predict the optimization of the Wawotobi irrigation network system.

Table 9. Results of Conformity Testing of Existing Condition Models

\begin{tabular}{|c|c|c|c|}
\hline Goodness of Fit Indeks & Cut of Value & Analysis Results & Model Evaluation \\
\hline Chi Square & Kecil & 44,769 & Small \\
\hline Probabability & $\geq 0,050$ & 0,083 & Good \\
\hline CMIN / DF & $\leq 2,000$ & 1,375 & Good \\
\hline GFI & $\geq 0,900$ & 0,933 & Good \\
\hline AGFI & $\geq 0,900$ & 0,933 & Good \\
\hline RMSEA & $\leq 0,080$ & 0,005 & Good \\
\hline
\end{tabular}

Table 10. Standardized Regression Weights Direct Influence of Latent Variables in Wawotobi Irrigation Networks

\begin{tabular}{|c|c|c|c|c|c|c|c|}
\hline \multicolumn{3}{|c|}{ Description } & Estimate & S.E & C.R. & P & information \\
\hline Real Condition & $<--$ & Performance & 0,129 & 0,014 & 0,584 & 0,006 & Significant \\
\hline
\end{tabular}

Based on the above equation it can be seen that the estimated value for performance is positive, which is equal to 0.129 , indicating that the performance of the Wawotobi
Estimated results of standardized regression weights, it can be seen the effect coefficient value, c.r (critical ratio) is the same as the t-test in the regression analysis and the level of probability of each direct relationship between latent variables. Based on the Amos output, the influence of the Existing Condition (KR) on Performance (KJ) obtained an estimated value of 0.129 , so that it can be mathematically expressed in the following equation:

information,

$\mathrm{KR}=$ Existing Condition

$\mathrm{KJ}=$ Performance

$\mathrm{e}=$ error variable irrigation network system has a positive effect on the existing condition of the Wawotobi irrigation network. 


\section{CONCLUSION}

Optimization Index between existing conditions and performance obtained an average value of CSI $=0.52$ is quite optimal. Based on SEM analysis that the estimated value for performance is positive, that is equal to 0.008 , for the analysis of the volume (VE) the debit pool is obtained in good condition, while for the coefficient of efficiency (CE) obtained 0.84 very efficient optimizations. The hydraulic condition performance of Wawotobi irrigation network system obtained a value of $62.46 \%$ with less optimal performance index. The influence of the performance condition $(\mathrm{KJ})$ model on the existing $(\mathrm{KR})$ model obtained $\mathrm{KR}=0.129 . \mathrm{KJ}+\mathrm{e}$ implies that the better the existing condition of the irrigation network, the better the performance of services.

\section{REFERENCES}

[1] Anshori, I., 2017. Earthing the Conception of IWRM in Indonesia, Medisa, Jakarta

[2] Sulawesi River Region Office IV. 2015. Hydrological data. Kendari

[3] Bardan, M, 2014. Irrigation. Graha Ilmu, Yogyakarta

[4] Efferin, S., Darmadji, S, H., Tan, Y, 2008. Accounting Research Methods, Revealing Phenomena with Qualitative and Quantitative Approaches. First Edition, Graha Ilmu, Yogyakarta.

[5] Ferdinand., 2005, Structural Equation Modeling. Key Library Series, BP Undip. Semarang.

[6] Ghozali, I., 2008, SEM, Theory, Concepts and Applications with the LISREL Program 8.54, Edition Two. UNDIP, Semarang.

[7] Gustian, Meri. 2014. Model Parameter Optimization Dr. Mock for Watershed Management. Syiah Kuala University. Banda Aceh.

[8] Hoe, S.L. 2008. Issues and Procedure in Adopting Structural Equation Modeling Technique, Journal of Applied Quantitave Methods, Volume 3 (1). 79-83.

[9] Joppe, M., Martin, D.W., Waalen J., 2001. Toronto's image as a destination: a comparative importance and satisfaction analysis, Travel Res., 39 (3): 252-260.

[10] Ministry of PUPR, 2018. Irrigation System Development and Management Program in Indonesia, Jakarta.

[11] Lensley K. Ray., Franzini B. Joseph, 1995. Water Resources Engineering Volume 1. Erlangga, Jakarta.
[12] Matzler, K., and Heischdemit, K.A., 2003, Importance Performance Analysis Revisited: the role of the Factor structure of Customer Satisfaction. The Service Industries Journal.

[13] Mirayani, Ima. 2013. Study of Groundwater Addition of the Villinger and Mock Method in the BandungSoreang Groundwater Basin. Faculty of Earth Sciences and Technology. Bandung Institute of Technology. Bandung.

[14] Minister of Public Works and Public Housing Regulation Number: 12 / PRT / M / 2015 Regarding Exploitation and Maintenance of Irrigation Networks. Jakarta

[15] Prasad, U.S., Umamahesh, N.V., and Viswanath, G.K. 2011. Optimal irrigation planning model for existing storage based irrigation systems in India, Journal of Irrigation Drainage Systems, 25: 19-38.

[16] Putra, Ade, A., 2016. The Model of Selection of Mass Public Transportation Facilities Based on Service Performance in the Mamminasata Corridor, Dissertation, Postgraduate at Haluoleo University, Kendari.

[17] Robertson, S.E. and Walker, S., 2000, Threshold Settings In Adaptive Filtering. Journal of Documentation, 56, pp. 312-331.

[18] Singh, A. 2013. Irrigation Planning and Management Through Optimization Modeling. Journal Water Management Manage, 28: 1-14.

[19] Supranto, J., 1997, Measurement of Customer Satisfaction Level, Jakarta: PT, Rineka Cipta.

[20] Widayanti, S., Yuliati, N. 2007. Economic Study on Organic Rice Farming in Sumberngepoh Village, Lawang District, Malang Regency, J-SEP Journal Vol. 1 No. 2.

[21] Wu, Y., Ji Chen, J., 2013. Estimating irrigation water demand using an improved method and optimizing reservoir operations for water supply and hydropower generation: A case study of the Xinfengjiang reservoir in southern China, Journal of Agricultural Water Management 116: 110- 121.

[22] Yamin, S and Kurniawan, H, 2009. SEM. Salemba Infotek. Jakarta.

[23] Yuliantri, Ricky. 2014. Optimization of Water Allocation for Irrigation Using Linear Programs. Faculty of Engineering. Bengkulu University. Bengkulu. 